\title{
KVALITETA ŽIVOTA I SAMOPOŠTOVANJE STUDENATA SVEUČILIŠTA U MOSTARU SMJEŠTENIH U STUDENTSKI DOM MOSTAR
}

\author{
Tajana Tadić ${ }^{1}$, Danijel Bevanda ${ }^{2}$, Dragan Babić ${ }^{1,2}$, Ivan Vasilj ${ }^{1,2}$, Marko Martinac ${ }^{1,2}$ \\ Fakultet zdravstvenih studija Sveučilišta u Mostaru ${ }^{1}$ \\ Medicinski fakultet Sveučilišta u Mostaru ${ }^{2}$ \\ Rad je primljen 15.1.2016. \\ Rad je korigiran 18.2.2016. \\ Rad je prihvaćen 25.3.2016.
}

\section{SAŽETAK}

UVOD: Kvaliteta života je subjektivno doživljavanje vlastitoga života određeno objektivnim okolnostima u kojima osoba živi. Važnu komponentu u kvaliteti života čini i samopoštovanje, a definira se kao rezultat formiranog pojma o sebi.

CILJ istraživanja bio je ispitati kvalitetu života i samopoštovanje studenata Sveučilišta u Mostaru smještenih u studentski dom.

ISPITANICI I METODE: Ispitnu skupinu činili su studenti smješteni u studentski dom (n=100), a kontrolnu skupinu činili su studenti koji žive s roditeljima $(n=80)$. Za potrebe istraživanja korišten je opći sociodemografski upitnik, SF-36 upitnik, te RSES upitnik.

REZULTATI: Studenti smješteni u studentski dom značajno više konzumiraju alkohol i cigarete u odnosu na studente koji žive s roditeljima. Muškarci u odnosu na žene bolje procjenjuju svoje fizičko funkcioniranje, te imaju veći osjećaj samopoštovanja u odnosu na žene. Studenti smješteni u studentski dom imaju značajno veći osjećaj samopoštovanja u odnosu na studente koji žive s roditeljima. Pokazala se značajno pozitivna korelacije između percepcije zdravlja i psihičkog zdravlja s osjećajem samopoštovanja.

ZAKLJUČAK: Studenti koji žive s roditeljima imaju veću kvalitetu života u odnosu na studente koji žive u studentskom domu, dok studenti koji su smješteni u studentski dom imaju značajno veći osjećaj samopoštovanja u odnosu na studente koji žive s roditeljima.

Ključne riječi: kvaliteta života, samopoštovanje, studenti, studentski dom

Osoba za razmjenu informacija:

Mag. sestrinstva: Tajana Tadić

E mail: ttadic10@gmail.com

\section{UVOD}

Kvaliteta života je multidimenzionalni pojam, te je predmet interesa mnogih disciplina, kao što su medicina, javno zdravstvo, pravo, filozofija, psihologija, ekonomija i sociologija (1). Sve više raste interes za znanstvenu analizu kvalitete življenja, odnosno proučavanje i praćenje stupnja u kojem pojedinci uživaju u svojim životima (2). Osnovni cilj istraživanja kvalitete života je prepoznavanje čimbenika koji doprinose ostvarivanju ciljeva i potencijala pojedinca, te življenju željenog životnog stila (3). Povijesno gledano dva su osnovna pristupa u mjerenju kvalitete života. Prema jednome kvaliteta života je jedinstven entitet, dok se drugom pristupu kvaliteta života poima kao složena konstrukcija diskretnih područja (4). Prilikom procjene kvalitete života na pojedinačnoj ili općoj razini populacije, postoji nekoliko zajedničkih problema mjerenja. Traganje za konačnim skupom ključnih dimenzija kvalitete života dalo je raznovrsne rezultate. Promatrajući opseg sa oko šezdeset instrumenata za procjenu kvalitete života korištenih u medicini, zaključuje se da većina instrumenata uzima u obzir tri ključne dimenzije kvalitete života: fizičku, psihološku i socijalnu (5). Socijalna podrška spominje se kao jedan od značajnijih činitelja koji doprinose kvaliteti života. Mnogi autori ukazuju na to da je socijalna podrška širok pojam 
koji je teško jednoznačno definirati, te ukazuju na to da se zapravo radi o različitim oblicima podržavajućeg ponašanja različitih ljudi u socijalnoj okolini (6). Da bi se bolje razumijelo socijalnu podršku, treba imati na umu da je ona zasnovana na socijalnoj zavisnosti - ovisnosti o drugima u zadovoljenju posebno socijalnih potreba. Socijalna zavisnost uključuje i zadovoljavanje potrebe za informacijama kroz interakcije s drugim ljudima (7). Predhodna istraživanja jasno su pokazala da studenti postižu nižu kvalitetu života u odnosu na opću populaciju, te da su vrijednosti u studentskim uzorcima homogenije. Izazovi i mogućnosti s kojima se mladi ljudi susreću tijekom svog studiranja su brojni i po mnogočemu specifični. Živjeti kao student uključuje različite promjene na kognitivnom, emocionalnom i društvenom području. Npr. promjene uključuju od promjena u količini vremena koja se posveti proučavanju nekog područja do razvijanja sustavnog i kritičkog razmatranja različitih prezentiranih činjenica, a ne samog mehaničkog usvajanja nekih znanja. Postoje brojne specifične norme vezane uz ovu populaciju koje određuju način života (npr. karakteristična studentska druženja i izlasci). Mnogi studenti se suočavaju s odvajanjem od roditelja i životom u nekoj novoj sredini. Može se reći da ovo životno razdoblje određuju različite prilagodbe. Pred studentima su mnogi izazovi čije uspješno svladavanje djeluje poticajno na samopoštovanje. Ovo je razdoblje u kojem se neki mladi po prvi put susreću s neuspjehom i uče se nositi i s posljedicama neuspjeha. Sve ove okolnosti mogu biti povezane s kvalitetom života mladih ljudi koji studiraju. Zdravstvena izvješća nekih zapadnih zemalja ukazuju na to da su problemi vezani za mentalno zdravlje češći u studenata nego što su to bili u prošlosti (8). Studentske savjetodavne službe izvještavaju o porastu broja studenata koji se obraćaju zbog problema u mentalnom zdravlju. Takvi problemi nadalje imaju negativan utjecaj na studentov kapacitet za studiranje i učenje, što pak dovodi do lošijeg akademskog uspjeha. Nije se pronašao empirijski dokaz da su studenti skloniji navedenim zdravstvenim poteškoćama. U mnogim se društvima zadnjih godina povećao pritisak na studente, kao rezultat rasta kompetitivnosti, financijskih zahtjeva društva, povećanih aspiracija za materijalnom sigurnosti i sl. Stoga se može pretpostaviti da će i potreba za podrškom u studenata biti veća i da će socijalna podrška imati važnu ulogu u kvaliteti njihovog života i svakodnevnom funkcioniranju (9). Važnu komponentu u kvaliteti života čini i samopoštovanje. Samopoštovanje se definira kao rezultat formiranog pojma o sebi tj. vrednovanje ili evaluacija sebe bilo na pozitivan ili na negativan način (10). Samopoštovanje predstavlja središnji aspekt samopoimanja. Samopoimanje označava psihološki konstrukt koji se može definirati kao fenomenološka organizacija iskustva pojedinca i ideja o njemu samom u svim aspektima njegova života. Pozitivno samopoimanje obično vodi ka konstruktivnom i socijalno poželjnom ponašanju, dok negativno može dovesti do devijantnog, socijalno neadekvatnog ponašanja (11). Osoba visokog samopoštovanja sebe uvažava, cijeni, smatra se vrijednom i općenito ima pozitivno mišljenje o sebi, dok osoba niskog samopoštovanja sebe obično ne prihvaća, podcjenjuje se i ima negativno mišljenje o sebi (12). Na razvoj samopoimanja pa tako i samopoštovanja značajni su odnosi pojedinca s drugima iz njegove socijalne okoline. Samopoštovanje (osjećaj ponosa ili srama) osobe ovisi o tome kako zamišlja da je prosuđuju drugi ljudi iz njezine okoline. Nisu sve interakcije u našem životu podjednake važnosti za stvaranje i mijenjanje pojma o sebi. Za niže uzraste interakcije s roditeljima presudne su za formiranje pojma o sebi (13). Samopoštovanje može utjecati na opću prilagodbu osobe, ponašanje u situacijama iskazivanja vlastitih mogućnosti, odabir socijalnih situacija i sudjelovanje osobe u njima. Kako je subjektivna procjena samopoštovanja povezana $s$ različitim manifestacijama ponašanja pojedinca, indirektno može utjecati i na moralno ponašanje, motivaciju i stavove osobe (14).

Cilj ovog straživanja bio je ispitati kvalitetu života i samopoštovanje studenata Sveučilišta u Mostaru smještenih u studentski dom i ispitati povezanost kvalitete života i samopoštovanja sa sociodemografskim karakteristikama. 


\section{ISPITANICI I METODE}

\section{Ispitanici}

Istraživanje je provedeno primjenom presječne studije, slučajnim odabirom među studentskom populacijom oba spola. Ispitnu skupinu činili su studenti koji su smješteni u studentski dom $(\mathrm{N}=100)$, a kontrolnu skupinu činili su studenti koji žive s roditeljima $(\mathrm{N}=80)$. Isključujući kriteriji za obje skupine bile su osobe koje u anamnezi imaju duševnu bolest ili duševni poremećaj kao i bilo koju drugu kroničnu bolest.

\section{Metode}

$\mathrm{U}$ istraživanju su korištena tri upitnika.

1. Opći sociodemografski upitnik osobne izrade, namjenski sačinjen (sačinjavao je opća pitanja: dob, spol, mjesto stanovanja, godinu i naziv studija, prosjek ocjena, matrijalne mogućnosti).

2. Standardizirani upitnik za procjenu kvalitete života, Short form health survey-36 (SF-36). SF-36 je često primjenjivani višenamjenski upitnik za samoprocjenu zdravstvenog stanja koji se sastoji od 36 pitanja (čestica). Čestica koja se odnosi na promjenu u zdravlju prikazuje se odvojeno, distribucijom frekvencija. SF-36 mjeri subjektivni osjećaj zdravlja kroz 8 različitih dimenzija zdravlja. Pojedine dimenzije zdravlja obuhvaćene su različitim brojem čestica, a njihov broj je empirijski utvrđen u skladu s psihometrijskim kriterijima pouzdanosti i valjanosti. Upitnik SF-36 reprezentira teorijski utemeljenu i empirijski provjerenu operacionalizaciju dva generalna koncepta zdravlja, kao što su tjelesno i mentalno zdravlje, te dvije njegove općenite manifestacije, funkcioniranje i dobrobit (15).

3. Standardizirani upitnik za procjenu samopoštovanja, Rosenberg Self-Esteem Scale (RSES). Skala mjeri globalnu vrijednosnu orijentaciju prema sebi. Sastoji se od 10 tvrdnji, 5 u pozitivnom i $5 \mathrm{u}$ negativnom smjeru. Ukupan rezultat određuje se zbrajanjem procjena na skali Likertovog tipa od 5 stupnjeva ( 1 = niti malo se ne odnosi na mene, $5=\mathrm{u}$ potpunosti se odnosi na mene). Visok rezultat odražava visoko samopoštovanje (16).

\section{Statistička analiza}

Distribucija vjerojatnosti kvantitativnih varijabli testirana je na normalnost Smirnov-Kolmogorovljevim testom. Podatci čija raspodjela varijabli nije odstupala od normalne prezentirani su kao aritmetičke sredine i standardne devijacije, te je pri utvrđivanju statističkih razlika rabljen t-test za nezavisne uzorke. Za prikaz srednje vrijednosti i mjere raspršenja kod kontinuiranih varijabli čija je raspodjela značajno odstupala od normalne korišteni su medijan i interkvartilni raspon, a za utvrđivanje razlika među skupinama koristio se Mann-Whitney U test. $\mathrm{Za}$ analizu nominalnih varijabli korišten je Hi kvadrat test.

Podatci prikupljeni upitnikom SF-36 transformirani su i sumirani u ljestvicu od 0 do $100 \%$ za svaku od osam dimenzija. Povezanost samoprocijenjenog zdravlja mjerenog SF-36 upitnikom i razine samopoštovanja procijenjena je Spearmanovim koeficijentom korelacije ranga. Mogućnost pogreške prihvatila se pri $a<0,05$ te su razlike između skupina bile prihvaćene kao statistički značajne za $\mathrm{p}<0,05$. $P$ vrijednosti koje se nisu mogle iskazati do najviše tri decimalna mjesta, prikazane su kao $\mathrm{p}<0,001$. Za statističku analizu dobivenih podataka rabljen je programski sustav SPSS for Windows (inačica 13.0, SPSS Inc, Chicago, Illinois, SAD) i Microsoft Excell (inačica Office 2007, Microsoft Corporation, Redmond, WA, SAD).

\section{REZULTATI}

Usporedbom sociodemografskih varijabli pokazala se statistički značajna rezlika među ispitivanim skupinama u odnosu na pijenje i pušenje. Ispitanici iz ispitivane skupine, $t \mathrm{j}$. studenti koji su smješteni $\mathrm{u}$ studenskom domu statistički značajno više puše cigarete $(\mathrm{p}=0,020)$ i redovitije piju alkohol $(\mathrm{p}=0,023)$. U odnosu na ostale sociodemografske karakteristike nije bilo statsitički značajne razlike (tablica 1 i 2). 
Tablica 1. Usporedba ispitivanih skupina u odnosu na sociodemografske varijable

\begin{tabular}{|c|c|c|c|c|}
\hline \multirow[b]{2}{*}{ Varijabla; N (\%) } & \multicolumn{2}{|c|}{ Smještaj studenta } & \multirow[b]{2}{*}{$\chi^{2}$} & \multirow[b]{2}{*}{$p$} \\
\hline & $\begin{array}{l}\text { Studentski } \\
\text { dom }\end{array}$ & $\begin{array}{c}\text { Roditeljska } \\
\text { kuća }\end{array}$ & & \\
\hline Spol & & & 0,588 & 0,380 \\
\hline Muški & $52(52,0)$ & $37(46,2)$ & & \\
\hline Ženski & $48(48,0)$ & $43(53,8)$ & & \\
\hline Pušenje & & & 5,328 & 0,020 \\
\hline $\mathrm{Da}$ & $67(67,0)$ & $40(50,0)$ & & \\
\hline $\mathrm{Ne}$ & $33(33,0)$ & $40(50,0)$ & & \\
\hline $\begin{array}{l}\text { Povremeno uzimanje } \\
\text { alkoholnih pića }\end{array}$ & & & 5,152 & 0,023 \\
\hline $\mathrm{Da}$ & $79(79,0)$ & $51(63,7)$ & & \\
\hline Ne & $21(21,0)$ & $29(26,3)$ & & \\
\hline
\end{tabular}

Tablica 2. Usporedba ispitivanih skupina u odnosu na sociodemografske varijable

\begin{tabular}{|c|c|c|c|c|}
\hline \multirow{2}{*}{ Varijabla; $\bar{X}$-SD } & \multicolumn{2}{|c|}{ Smještaj studenta } & \multirow{2}{*}{ t-test } & \multirow{2}{*}{$p$} \\
\hline & Studentski dom & Roditeljska kuća & & \\
\hline Dob & $21,9-1,3$ & $22,0-1,4$ & 0,166 & 0,868 \\
\hline Materijalne mogućnosti & $3,5-1,1$ & $3,3-0,8$ & 1,558 & 0,121 \\
\hline Akademski uspjeh & $2,6-0,9$ & 2,9-1,1 & 1,525 & 0,129 \\
\hline
\end{tabular}

$\bar{X}$ - aritmetička sredina; SD - standardna devijacija

Rezultati samoprocjenjenog osjećaja zdravlja ispitanika kroz osam dimenzija zdravlja prikazani su kao srednje vrijednosti u tablici 3. Usporedbom pet dimenzija zdravlja koje opisuju fizičko funkcioniranje $(\mathrm{PF})$, tjelesne bolove $(\mathrm{BP})$, percepciju općeg zdravlja (GH), vitalnost i energiju (VT) i socijalno funkcioniranje (SF) nije se pokazala statistički značajna razlika među ispitivanim skupinama. Što se tiče ograničenja zbog fizičkih teškoća (RP), ispitanici iz kontrolne skupine postigli su statistički značajno veće rezultate na ovoj ljestvici $(\mathrm{p}=0,011) \mathrm{u}$ odnosu na ispitivanu, što znači da su bili manje ograničeni zbog fizičkih teškoća. Ispitanici iz kontrolne skupine pokazali su statistički značajno manja ograničenja zbog emocionalnih poteškoća (RE) $(\mathrm{p}=0,001)$. Ocjena psihičkog zdravlja pokazala je statistički značajnu razliku. Ispitanici iz ispitne skupine svoje su psihičko zdravlje $(\mathrm{MH})$ ocijenili statistički značajno većom ocjenom $(\mathrm{p}<0,001) \mathrm{u}$ odnosu na ispitanike iz kontrolne skupine.
Tablica 3. Razlike u domenama SF-36 izmedu ispitivanih skupina

\begin{tabular}{|c|c|c|c|c|}
\hline \multirow[b]{2}{*}{ Domene SF-36; M (Ir)* } & \multicolumn{2}{|c|}{ Smještaj studenta } & \multirow[b]{2}{*}{ Z } & \multirow[b]{2}{*}{$\mathrm{p}^{\dagger}$} \\
\hline & $\begin{array}{c}\text { Studentski } \\
\text { dom }\end{array}$ & $\begin{array}{l}\text { Roditeljska } \\
\text { kuća }\end{array}$ & & \\
\hline Fizičko funkcioniranje (PF) & $96,6(16,3)$ & $96,6(16,9)$ & $-0,502$ & 0,616 \\
\hline $\begin{array}{l}\text { Ograničenje zbog fizičkih } \\
\text { teškoća (RP) }\end{array}$ & $91,8(14,3)$ & $96,3(13,2)$ & $-2,554$ & 0,011 \\
\hline Tjelesni bolovi (BP) & $33,1(4,5)$ & $35,8(5,0)$ & $-0,731$ & 0,322 \\
\hline Percepcija oṕ́eg zdravlja (GH) & $75,6(11,2)$ & $75,6(10,2)$ & $-1,382$ & 0,167 \\
\hline Vitalnost i energija (VT) & $81,5(22,7)$ & $81,5(13,6)$ & $-1,067$ & 0,286 \\
\hline Socijalno funkcioniranje (SF) & $62,5(12,5)$ & $62,5(12,1)$ & $-1,561$ & 0,118 \\
\hline $\begin{array}{l}\text { Ograničenje zbog emocionalnih } \\
\text { teškoća (RE) }\end{array}$ & $69,0(17,2)$ & $75,9(12,9)$ & $-3,444$ & 0,001 \\
\hline Psihičko zdravlje (MH) & $64,9(8,0)$ & $61,7(4,2)$ & $-3,612$ & $<0,001$ \\
\hline
\end{tabular}

*M (Ir) - Medijan (Interkvartilni raspon); †'Mann-Whitney U test

Pokazala se statistički značajna razlika u samoprocjeni fizičkog funkcioniranja među ispitanicima u odnosu na njihovu spolnu pripadnost. Muškarci u odnosu na žene, statistički značajno bolje procjenjuju svoje fizičko funkcioniranje ( $p=0,031)$. Raščlamba rezultata ostalih domena u upitniku nije pokazala statistički značajnu razliku (tablica 4).

Tablica 4. Razlike u domenama SF-36 u odnosu na spolnu pripadnost cjelokupnog uzorka ispitanika

\begin{tabular}{|c|c|c|c|c|}
\hline \multirow[b]{2}{*}{ Domene SF-36; M (IIr)* } & \multicolumn{2}{|c|}{ Smještaj studenta } & \multirow[b]{2}{*}{ Z } & \multirow[b]{2}{*}{$\mathrm{p}^{\dagger}$} \\
\hline & $\begin{array}{c}\text { Studentski } \\
\text { dom }\end{array}$ & $\begin{array}{l}\text { Roditeljska } \\
\text { kuća }\end{array}$ & & \\
\hline Fizičko funkcioniranje (PF) & $96,6(6,9)$ & $91,3(10,3)$ & $-2,161$ & 0,031 \\
\hline $\begin{array}{l}\text { Ograničenje zbog fizičkih } \\
\text { teškoća (RP) }\end{array}$ & $97,7(14,3)$ & $97,3(13,2)$ & $-1,080$ & 0,280 \\
\hline Tjelesni bolovi (BP) & $36,7(6,5)$ & $35,8(5,0)$ & $-1,217$ & 0,224 \\
\hline Percepcija općeg zdravlja (GH) & $75,5(7,4)$ & $75,6(11,2)$ & $-0,220$ & 0,826 \\
\hline Vitalnost i energija (VT) & $85,5(18,1)$ & $80,0(12,8)$ & $-1,782$ & 0,075 \\
\hline Socijalno funkcioniranje (SF) & $62,5(12,5)$ & $62,5(12,0)$ & $-0,057$ & 0,954 \\
\hline $\begin{array}{l}\text { Ograničenje zbog emocionalnih } \\
\text { teškoća (RE) }\end{array}$ & $75,9(17,3)$ & $72,4(13,8)$ & $-1,097$ & 0,273 \\
\hline Psihičko zdravlje (MH) & $63,8(7,4)$ & $61,7(6,4)$ & $-1,259$ & 0,208 \\
\hline
\end{tabular}

${ }^{*} \mathrm{M}$ (Ir) - Medijan (Interkvartilni raspon); ‘ Mann-Whitney U test

Pokazala se statistički značajna razlika u percepciji općeg zdravlja među ispitanicima u odnosu na ocjenu svojih materijalnih mogućnosti. Ispitanici s ocjenom svojih materijalnih mogućnosti 1-3 imaju značajno bolju percepciju svog općeg zdravlja u odnosu na ispitanike koji su svoje materijalne mogućnosti ocijenili ocjenom 4-5 ( $\mathrm{p}=0,047)$. Raščlamba 
rezultata ostalih domena u upitniku nije pokazala statistički značajnu razliku (tablica 5).

Tablica 5. Razlike u domenama SF-36 u odnosu na materijalne mogućnosti cjelokupnog uzorka ispitanika

\begin{tabular}{|c|c|c|c|c|}
\hline Domene SF-36; M (Ir)* & $\begin{array}{c}\text { Ispitanicisa } \\
\text { slabijim matrijalnim } \\
\text { mogućnostima }\end{array}$ & $\begin{array}{l}\text { Ispitanicis boljim } \\
\text { matrijalnim } \\
\text { mogućnostima }\end{array}$ & Z & $\mathrm{p}^{\dagger}$ \\
\hline $\begin{array}{l}\text { Fizičko funkcioniranje } \\
\text { (PF) }\end{array}$ & $96,6(10,3)$ & $96,6(8,9)$ & $-1,185$ & 0,236 \\
\hline $\begin{array}{l}\text { Ograničenje zbog } \\
\text { fizičkih teškoća (RP) }\end{array}$ & $97,8(14,3)$ & $97,5(13,7)$ & $-0,566$ & 0,571 \\
\hline Tjelesni bolovi (BP) & $36,7(5,5)$ & $35,8(4,3)$ & $-0,598$ & 0,550 \\
\hline $\begin{array}{l}\text { Percepcija općeg } \\
\text { zdravlja (GH) }\end{array}$ & $75,6(11,4)$ & $71,9(11,2)$ & $-1,599$ & 0,047 \\
\hline Vitalnost i energija (VT) & $85,5(17,1)$ & $85,3(15,6)$ & $-0,139$ & 0,869 \\
\hline $\begin{array}{l}\text { Socijalno } \\
\text { funkcioniranje (SF) }\end{array}$ & $62,5(12,5)$ & $62,5(12,1)$ & $-1,274$ & 0,203 \\
\hline $\begin{array}{l}\text { Ograničenje zbog } \\
\text { emocionalnih teškoća } \\
\text { (RE) }\end{array}$ & $72,4(13,8)$ & $72,4(16,4)$ & $-0,384$ & 0,701 \\
\hline Psihičko zdravlje (MH) & $63,8(6,4)$ & $61,7(6,4)$ & $-0,205$ & 0,838 \\
\hline
\end{tabular}

${ }^{*} \mathrm{M}(\mathrm{Ir})$ - Medijan (Interkvartilni raspon); ${ }^{\dagger}$ Mann-Whitney U test

Pokazala se statistički značajna razlika u domeni vitalnosti i energije među ispitanicima u odnosu na njihovu naviku pijenja alkohola (tablica 6). Ispitanici koji ne piju alkohol imaju statistički značajno bolji osjećaj vitalnosti i energije u odnosu na ispitanike koji povremeno piju alkohol $(\mathrm{p}=0,004)$.

Tablica 6. Razlike u domenama SF-36 u odnosu na naviku konzumiranja alkohola cjelokupnog uzorka ispitanika

\begin{tabular}{|c|c|c|c|c|}
\hline $\begin{array}{l}\text { Domene SF-36; M } \\
(\text { (Ir) })^{*}\end{array}$ & $\begin{array}{c}\text { Ispitanici koji } \\
\text { povremeno } \\
\text { konzumiraju alkohol }\end{array}$ & $\begin{array}{l}\text { Ispitanici koji nikada } \\
\text { ne konzumiraju } \\
\text { alkohol }\end{array}$ & Z & $p$ \\
\hline $\begin{array}{l}\text { Fizičko funkcioniranje } \\
\text { (PF) }\end{array}$ & $96,6(10,3)$ & $96,6(6,8)$ & $-0,116$ & 0,908 \\
\hline $\begin{array}{l}\text { Ograničenje zbog } \\
\text { fizičkih teškoća (RP) }\end{array}$ & $98,6(14,1)$ & $98,5(13,8)$ & $-1,482$ & 0,141 \\
\hline Tjelesni bolovi (BP) & $33,1(4,3)$ & $32,3(4,0)$ & $-1,234$ & 0,217 \\
\hline $\begin{array}{l}\text { Percepcija općeg } \\
\text { zdravlja (GH) }\end{array}$ & $75,5(10,1)$ & $75,6(11,3)$ & $-1,683$ & 0,087 \\
\hline $\begin{array}{l}\text { Vitalnost i energija } \\
\text { (VT) }\end{array}$ & $80,0(19,3)$ & $70,9(10,2)$ & $-2,906$ & 0,004 \\
\hline $\begin{array}{l}\text { Socijalno } \\
\text { funkcioniranje (SF) }\end{array}$ & $62,5(12,5)$ & $62,4(12,1)$ & $-0,138$ & 0,789 \\
\hline $\begin{array}{l}\text { 0graničenje zbog } \\
\text { emocionalnih teškoća } \\
\text { (RE) }\end{array}$ & $72,4(14,7)$ & $72,4(13,0)$ & $-0,051$ & 0,953 \\
\hline $\begin{array}{l}\text { Psihičko zdravlje } \\
\text { (MH) }\end{array}$ & $63,8(8,5)$ & $62,7(6,4)$ & $-0,927$ & 0,354 \\
\hline
\end{tabular}

*M (Ir) - Medijan (Interkvartilni raspon); †'Mann-Whitney U test
Usporedbom srednjih vrijednosti rezultata osjećaja samopoštovanja među ispitivanim skupinama pokazala se statistički značajna razlika (tablica 7 ). Ispitanici koji su smješteni u studentskom domu imaju značajno veći osjećaj samopoštovanja u odnosu na ispitanike koji su smješteni kod roditelja $(p<0,001)$

Tablica 7. Razlike u osjećaju samopoštovanja između ispitivanih skupina

\begin{tabular}{|c|c|c|c|c|}
\hline & \multicolumn{2}{|c|}{ Smještaj studenta } & \multirow[b]{2}{*}{ Z } & \multirow[b]{2}{*}{$\mathrm{p}^{\dagger}$} \\
\hline & $\begin{array}{c}\text { Studentski } \\
\text { dom }\end{array}$ & $\begin{array}{l}\text { Roditeljska } \\
\text { kuća }\end{array}$ & & \\
\hline Osjećaj samopoštovanja M (Ir)* & $31,5(3,8)$ & $30,0(2,0)$ & $-3,612$ & $<0,001$ \\
\hline
\end{tabular}

Pokazala se statistički značajna razlika među ispitanicima u odnosu na njihovu spolnu pripadnost (tablica 8). Muškarci imaju statistički značajno veći osjećaj samopoštovanja u odnosu na žene $(\mathrm{p}=0,002)$.

Tablica 8. Razlike u osjećaju samopoštovanja u odnosu na spolnu pripadnost cjelokupnog uzorka ispitanika

\begin{tabular}{lcccc}
\hline & Muškarci & Žene & Z & p $^{\dagger}$ \\
\hline 0sjećaj samopoštovanja M (II) ${ }^{*}$ & $31,0(3,5)$ & $29,0(2,0)$ & $-3,086$ & 0,002 \\
\hline
\end{tabular}

*M (Ir) - Medijan (Interkvartilni raspon); ‘'Mann-Whitney U test

U tablici 9. prikazani su Spearmanovi koeficijenti korelacije rangova između osam dimenzija zdravlja mjerenih upitnikom SF-36 i osjećaja samopoštovanja mjerenog Standardiziranim upitnikom za procjenu samopoštovanja (RSES). Pokazala se statistički značajna pozitivna korelacija između percepcije općeg zdravlja $(\mathrm{p}=0,003)$ i psihičkog zdravlja $(\mathrm{p}<0,001) \mathrm{s}$ osjećajem samopoštovanja. To znači da su veća percepcija općeg zdravlja i bolji osjećaj psihičkog zdravlja značajno povezani s višim osjećajem samopoštovanja u ispitanika.

Tablica 8. Povezanost samoprocjenjenog zdravlja $i$ osjećaja samopoštovanja utvrđena Spermanovim koeficijentom korelacije

Domene SF-36 0sjećaj samopoštovanja 


\begin{tabular}{lcc}
\hline Fizičko funkcioniranje (PF) & 0,010 & 0,890 \\
0graničenje zbog fizičkih teškoća (RP) & 0,036 & 0,631 \\
Tjelesni bolovi (BP) & 0,118 & 0,116 \\
Percepcija općeg zdravlja (GH) & 0,220 & 0,003 \\
Vitalnost i energija (VT) & 0,013 & 0,865 \\
Socijalno funkcioniranje (SF) & 0,083 & 0,270 \\
Ograničenje zbog emocionalnih teškoća (RE) & 0,003 & 0,972 \\
Psihičko zdravlje (MH) & 0,780 & $<0,001$ \\
\hline
\end{tabular}

\section{RASPRAVA}

Rezultatima dobivenih istraživanjem utvrđeno je da studenti koji žive s roditeljima imaju veću kvalitetu života u odnosu na studente koji žive u studentskom domu, dok je samopoštovanje veće kod studenata koji žive u studentskom domu. Pokazalo se da spol, matrijalne mogućnosti, konzumiranje alkohola, te samoprocjenjeni osjećaj zdravlja znatno utječu na kvalitetu života i samopoštovanje cjelokupnog uzorka ispitanika. Analizom rezultata pokazalo se da muškarci u odnosu na žene bolje procjenjuju svoje fizičko funkcioniranje, dok najnoviji rezultati nacionalne studije kvalitete života u Australiji govore o višim vrijednostima samoprocijenjene kvalitete života za žene u odnosu na muškarce. U istraživanjima provedenim u zapadnim zemljama nije nađena razlika u subjektivnoj kvaliteti života između muškaraca i žena (17). Prema rezultatima pokazala se statistički značajna razlika u percepciji općeg zdravlja među ispitanicima u odnosu na njihove materijalne mogućnosti. Ispitanici sa slabijim materijalnim mogućnostima imaju značajno bolju percepciju svog općeg zdravlja u odnosu na ispitanike koji imaju bolje materijalne mogućnosti. Drugi istraživači navode da niži socioekonomski status pojedinca odnosno pripadnosti nižoj socijalnoj klasi povećava rizik od nastanka različitih zdravstvenih problema i doprinosi osjećaju lošijeg samoprocjenjenog zdravlja. Brojni istraživači ističu upravo povezanost siromaštva $s$ lošijim zdravljem, pri čemu smatraju da dugotrajna niža razina prihoda jače utječe na zdravlje u negativnom smislu, odnosno da je trajno siromaštvo više štetno za zdravlje nego povremene epizode, te da smanjenje prihoda ima veći utjecaj na zdravlje nego njegovo povećanje $(18,19)$. Rezultati pokazuju da velika većina ispitanika oba spola konzumira alkohol, te da ispitanici koji ne konzumiraju alkohol imaju statistički značajno bolji osjećaj vitalnosti i energije u odnosu na ispitanike koji nikada ne konzumiraju alkohol. Druga istraživanja su pokazala kako je čak preko 90 \% studenata u Europi u svom dosadašnjem životu konzumiralo alkohol. Vezano uz konzumaciju alkohola u studentskoj populaciji, recentna istraživanja su pokazala kako unatoč spomenutom smanjivanju razlika između muškog i ženskog spola, između njih i dalje postoji razlika u razinama konzumacije, dok su različita istraživanja došla do proturječnih rezultata, vezano uz povezanost razine konzumacije alkohola s akademskom uspješnosti studenata, područjem znanosti fakulteta na kojem studiraju, te mjestom njihova stanovanja tijekom studija (20). Pokazalo se da muškarci imaju statistički značajno veći osjećaj samopoštovanja u odnosu na žene što se slaže s podatcima drugih istraživanja. Žene općenito imaju niže samopoštovanje od muškaraca. Do tog zaključka su došli Alpert Gillis \& Connel, Brutsaert u svojim istraživanjima (prema Van Houtte, 2005). Muškarci grade svoje samopoštovanje na svom položaju u grupi (gdje se nalaze u hijerarhijskoj ljestvici). Oni razvijaju svoje samopoštovanje na injenici da su bolji od drugih. Suprotno tome, žensko samopoštovanje je usmjereno više interpersonalno. One povezuju svoje samopoštovanje s međusobnom ovisnošu s drugima, te time pridaju veću važnost tuđim reakcijama na njihovo ponašanje (21). Istraživanja koja su do sada provedena rezultirala su jednim od dva zaključka. Jedan je da ne postoje značajne razlike između muškog i ženskog spola, dok se također navodi da muškarci imaju veće samopoštovanje od žena, neovisno o dobnoj skupini. Brojna istraživanja su izvijestila o nepostojanju značajne razlike između muškaraca i žena (22). Statistički značajno veći broj pušača je među studentima koji žive u studentskom domu. Moguća objašnjenja takvih rezultata su veća sloboda studenata, manji roditeljski nadzor. Zastupljenost konzumacije cigareta među studentskom populacijom javlja se i u drugim istraživanjima. Epidemiološki podaci u Poljskoj su pokazali da su studenti započinjali redovnu konzumaciju cigareta u 18. i 20. godini (23). Pokazala se statistički značajna pozitivna korelacija 
između percepcije općeg zdravlja i psihičkog zdravlja s osjećajem samopoštovanja. To znači da su veća percepcija općeg zdravlja i bolji osjećaj psihičkog zdravlja značajno povezano s višim osjećajem samopoštovanja u ispitanika. Takva povezanost dobivena je i u ranijim istraživanjima, npr. Honga i Giannakopoulosa koji su dobili nalaz da je samopoštovanje najjači prediktor zadovoljstva životom (24). Većina autora se slaže da samopoštovanje u razdoblju adolescencije igra veliku ulogu u brojnim aspektima života pojedinaca. Visoke, odnosno niske razine samopoštovanja često utječu na ponašanje pojedinca, njegove izbore u životu te odnose s drugima. Postoje neslaganja među autorima kada je riječ o stabilnosti odnosno promjenama u razini samopoštovanja. Neki tvrde da je samopoštovanje stabilno tijekom života dok drugi govore o promjeni, koja zbog brojnih razvojnih zadataka u tom razdoblju, najviše karakterizira upravo adolescenciju (25).

\section{ZAKLJUČAK}

1. Studenti koji žive s roditeljima imaju statistički značajno manje fizičke teškoće i manja ograničenja zbog emocionalnih poteškoća u odnosu na studente koji su smješteni u studentskom domu.

2. Studenti koji su smješteni u studentskom dobu imaju statistički značajno bolju procjenu svog psihičkog zdravlja u odnosu na studente koji žive s roditeljima.

3. Muškarci u odnosu na žene statistički značajno bolje procjenjuju svoje fizičko funkcioniranje.

4. Studenti koji su smješteni u studentskom domu imaju značajno veći osjećaj samopoštovanja u odnosu na student koji su smješteni kod roditelja.

5. Veća percepcija općeg zdravlja i bolji osjećaj psihičkog zdravlja značajno su povezani s većim osjećajem samopoštovanja u ispitanika.

6. Studenti koji žive s roditeljima imaju veću kvalitetu života u odnosu na studente koji žive u studentskom domu.

\section{LITERATURA}

1. Skevington SM, Lotfy M, O'Connell KA. The World Health Organization's WHOQOL-BREF quality of life assessment: psychometric proper- ties and results of the international field trial. A report from the WHOQOL group. Qual Life Res 2004;13:299-310.

2. Veenhoven, R. Apparent Quality of life in nations: How long and happy people live?, Social Indicators Research, 2005;71:61-68.

3. Bejaković P., Kaliterna Lipovčan, Lj. Quality of life in Croatia: Key ndings from national research, Dublin: European Foundation for the Improvement of Living and Working Conditions. 2007.

4. Breslin, S. Quality of life: How is it measured and defined? Urologia Internationalis, 1991;46:24651.

5. Beauchamp TL. Does Ethical Theory Have a Future in Bioethics? J Law Med Ethics 2004;32:209-17.

6. Hengelson, V.S. Social support and quality of life. Quality of Life Research, 2003; 12:25-31.

7. Helgeson, V.S. Two important distinctions in social support: Kind of support and perceived vs. received. Journal of Applied Social Psychology, 1993;23:825-45.

8. Council Report: The mental health of students in higher education Royal College of Psychiatrists, London, 2003.

9. Cummins, R.A. Normative life satisfaction: Measurement issues and a homeostatic model. Social Indicators Research. 2003;64:225-56.

10. Fleming, J. S. \& Courtney, B. E. The dimensionality of self-esteem: II. Hierarchical facet model for revised measurement scales. Journal of Personality and Social Psychology, 1984;46:404-21.

11.Lacković-Grgin, K. Samopoimanje mladih. Jastrebarsko: Naklada Slap; 1994.

12. Coopersmith, S. The Antecedents of Self esteem. San Francisco: Freeman; 1967.

13.Lebedina-Manzoni, M. Psihološke osnove poremećaja u ponašanju. Jastrebarsko: Naklada Slap; 2007.

14.Pastor, I. Samopoštovanje djece $s$ obzirom na spol, dob i mjesto stanovanja. Neobjavljeni diplomski rad. Zagreb: Odsjek za psihologiju, Filozofski fakultet Sveučilišta u Zagrebu; 2004.

15. Bowling, A. What things are important in people's lives? A survey of the public's judgements to 
inform scales of health related quality of life. Soc. Sci. and Medicine, 1995;41;10:1447

16. McDowell I. Measuring Health. A guide to Rating Scales and Questionnaires. 3rd Edition ed. New York: Oxford University Press; 2006.

17. AustralianUnity Well-being index. (Internet) Pristupljeno: 18.09.2015. Dostupno: http://acqol. deakin.edu.au/index_wellbeing/index.htm

18. Lee S, Kawachi I, Berkman LF, Grodstein F. Education, other socioeconomic indicators and cognitive function. Am J Epidemiol 2003;157:71220.

19. McFadden E, Luben R, Bingham S, Wareham $\mathrm{N}$, Kinmonth A, Khaw KT. Social inequalities in self-rated health by age: cross-sectional study of 22.457 middle-aged men and women. BMC Public Health. 2008;8:230.

20. Sebena R, Orosova O, Mikolajczyk RT, van Dijk JP. Selected sociodemographic factors and related differences in patterns of alcohol use among university students in Slovakia. BMC Public Health, 2011;11:849.

21. Van Houtte, M. Global self-esteem in techni$\mathrm{cal} /$ vocational versus general secondary school tracks:a matter of gender? Sex Roles:A Journal of Research; 2005.
22. Feingold, A. Gender differences in Personality: a meta-analysis. Psychological Bulletin, 1994;116:429-456.

23. Kuznar-Kaminska B, Brajer B, Batura-Gabryel H, Kaminski J. Tobacco smoking behavior among high school students in Poland. J Physiol Pharmacol 2008;59 Suppl 6:393-9.

24. Mecca, A.M., Smelser, N.J. i Vasconcellos, J. The social importance of selfesteem. Los Angeles: University of California Press, Ltd 1989.

25. Trzesniewski, K.H., Donnellan, M.B. i Robins, R.W. Stability of self-esteem across the life span. Journal of Personality and Social Psychology, 2003;84:200-20. 


\title{
QUALITY OF LIFE AND SELF-ESTEEM OF STUDENTS AT UNIVERSITY OF MOSTAR LOCATED IN THE STUDENT DORMITORY
}

\author{
Tajana Tadić, Danijel Bevanda, Dragan Babić, Ivan Vasilj, Marko Martinac \\ Faculty of Health Sciences, University of Mostar
}

\begin{abstract}
INTRODUCTION: The quality of life is a subjective experience of your own life determined by objective circumstances in which the person lives. Self-esteem makes an important component in the quality of life, and it is defined as a result of formed sense of self.

OBJECTIVE: The objective of the research was to investigate the quality of life and self-esteem of students at the University of Mostar located in the student dormitory.

SUBJECTS AND METHODS: The test group consisted of students in the student dormitory $(\mathrm{n}=100)$, while the control group consisted of students who live with their parents $(n=80)$. For research purposes we used the general socio-demographic questionnaire, the SF-36 questionnaire, and the RSES questionnaire.

RESULTS: Students situated in the dormitory consume significantly more alcohol and cigarettes, as opposed to students who live with their parents. Men compared to women have a better evaluation of their physical functioning and a higher self-esteem. Students housed in the student dormitory have significantly higher self-esteem than the students who live with their parents. The research pointed out a considerably positive correlation between the perception of health and mental health with the sense of self-esteem.

CONCLUSION: Students who live with their parents have a higher quality of life when compared to students living in dorms, while students placed in the student dormitory have significantly higher self-esteem than the students who live with their parents.
\end{abstract}

Key words: quality of life, self-esteem, students, student dormitory

Correspondence: Tatjana Tadić, Master of Nursing

E-mail: ttadic10@gmail.com 